\title{
An Aesthetic Approach in Arts Learning at the Department of Visual Arts Education Yogyakarta State University
}

\author{
Fauziah Dwi Rohmawati ${ }^{1 *}$ Trie Hartiti Retnowati ${ }^{1,}$ Zulfi Hendri ${ }^{1}$
}

${ }^{1}$ Yogyakarta State University, Yogyakarta, Indonesia

*Corresponding author.Email: fauziahdwirohmawati@gmail.com

\begin{abstract}
This article investigated the aesthetic approach in arts learning implemented by the Arts Education Department, Yogyakarta State University. This was a qualitative descriptive study that aimed to describe the main components of the aesthetic approach in arts learning that leads to the development of competencies and attitudes in social and artistic life. The data collection techniques used in this study were observation, interviews, and documentation. The data were analyzed through data reduction, data display, and data verification. The results of the study show that the Department of Visual Arts Education applies an aesthetic approach including representation, expressionism, and formalism in several courses. The three methods in this aesthetic approach are used for the aim of preparing competent and character-oriented teachers in the Visual Arts Education Department.
\end{abstract}

Keywords: Arts Education, Aesthetic Approach, Competence, Character

\section{INTRODUCTION}

The Department of Arts Education, Faculty of Languages and Arts, Yogyakarta State University, produces arts teachers in Yogyakarta. The main objective of this department is to produce prospective art teachers with competence and character. To realize it, Visual Arts Education has designed a learning curriculum that not only hones the ability to make artwork but also provides a stimulus for students to acquire the competence and character of art teachers. This department applies various approaches in the learning activities; one of the main things is aesthetic sensitivity. Therefore, how can an aesthetic approach produce prospective teachers with competence and character?

This article provides an overview of arts learning based on an aesthetic approach applied by the Visual Arts Education Department. The approach in this study refers to the three types of the aesthetic approach of DBAE, namely art representation, art expressionism, and art formalism. Furthermore, the authors describe the effect of the aesthetic approach on the preparation of competent and characteroriented arts teachers.

\section{LITERATURE REVIEW}

An education process is considered successful if it can improve the human potential in three main dimensions, namely knowledge, attitudes, and skills. This applies to almost all types of education, including arts education. In her writing, Michelle Lynn Loudermilk explains that arts education does not only focus on its products but also its aim to provide the students with knowledge and opportunities to understand and appreciate arts [1].

If we explore what art is, the explanation surely will be very complex. Upitis [4] said that when we can make sense of what someone does, and feelings such as happiness or sadness arise after that, it is regarded as an art. Art, in this case, is of course related to both taste and knowledge. To feel and value things they encounter, humans need to have aesthetic sensitivity. The learning of sensitivity mentioned in this study has a wide scope, not only to enjoy the beauty that exists but also to find the reason behind the aesthetics and what effects arise from it. In addition, beauty and its effect can be noticed subjectively or objectively. 
The process related to art literacy is not a passive understanding, but it is the knowledge that is dynamic and develops in a complex manner, thus motivating humans to perform an artistic act. The development of artistic literacy encourages students to use their cognitive skills in interpretation and evaluation to produce action dispositions. It is a change in the attitude component or adaptation [6]. This shows a feeling of giving opportunities to students to shape their characters from different sides based on the level of artistic literacy they perceive. It is like a movie that can provide the audience with the chance to feel and interpret the plots based on their interpretation. A movie can create many different messages and moral values felt by the audience depending on how critical their aesthetic sensitivity is. This certainly will affect their sympathy and empathy for the roles in the movie.

Aesthetic education is a type of humanist education that provides more portions for students to cultivate their affective and psychomotor dimensions [2]. The concept of a more complete aesthetic education curriculum developed at the same time as the rise of Discipline-Based Art Education (DBAE) in 1983. The aesthetic approach used in DBAE offers a broader interpretation of art through representation, expressionism, and formalism methods [1].

Representation includes imitation and mimesis, which aims to present a reality in which art reflects the object. The theory of representation was born with a long history by Plato and Aristotle. The concept of art initiated by Plato is a pure imitation of the subject of creation, and there is no other element outside the subject depicted. In arts learning, an example of applying the initial concept of mimesis is the creation of realistic artworks. Furthermore, students can look for alternative styles of creation based on their interests and characters.

The next aesthetic approach is expressionism; this approach refers to the depiction of the mood and expression of the artist's emotions. Art is a means to show emotional forms that include ideas, moods, attitudes, and points of view. Alternative learning with an expressionism approach can be executed by teaching students to describe their mood toward an artwork. The third approach is formalism; aesthetics in formalism is viewed from the work structure. The play of the visual art elements in a work is noticed from the principle of creating artworks.

When students interpret a problem through these three methods, they can think more critically and see art from a different and broader side. Aesthetic sensitivity cannot be felt easily; a process of aesthetic experience takes place continuously. This process will be easier if it involves the teacher's role as a motivator in it because external stimuli are the main determining factors for the success of art education based on an aesthetic approach. The teacher should be competent to effectively guide students to explore the aesthetic side with the right literacy.

In the era of postmodernism, imbalance in the field of education occurs where rationality and reason are the main interests [5]. Often, humanist education such as arts is underestimated because it is considered as less significant learning for students' intelligence. This is based on many facts, one of which is the number of Arts and Culture teachers who do not have the competence as art teachers. These teachers teach knowledge and skills irrelevant to their background. Therefore, it is very important to restore the essence of education in this postmodern era to the processing of cognitive, affective, and psychomotor abilities.

At the beginning of this article, it has been clearly explained that arts education with an aesthetic approach can shape children's character if the teachers are competent. In addition to playing a role in fostering imagination and training students' artistic work skills, teachers should also be able to evoke student appreciation of arts. Munteanu et al. [3] explain the reasons behind the significance of having professional teachers in arts learning. The competence and character of a professional teacher can improve self-motivation and scientific understanding. This can help promote learning methods that can improve students' learning interests. Through such learning, the students not only gain knowledge but also take the moral values.

The main requirement for teachers who are competent in aesthetic education is being able to understand the concepts of appreciation and artistic expression. In this paper, the author describes the implementation of art education based on an aesthetic approach in the Visual Arts Education Department.

\section{METHOD}

The problem of the research is arts learning in the Visual Arts Education Department based on the aesthetic approach. Based on these problems, the authors decided to use a descriptive qualitative method. The background of the research was the Department of Visual Arts Education, Faculty of Languages and Arts, Yogyakarta State University. This article provides an overview of aesthetic sensitivity education in order to prepare prospective teachers of arts in the department.

The data were collected through observation, interview, and documentation techniques. The researchers observed the learning activities in practical and theoretical courses in the Arts Education Department. Furthermore, through this observation, 
the researcher could find out how aesthetic sensitivity was taught to students. The interviews were conducted with the academic community, including lecturers and students in the department. The documentation of this research included data collection of the Semester Lesson Plans as the learning instrument.

This study employed a descriptive data analysis that referred to the interactive model formulated by Miles and Huberman. The data analysis was carried out through the stages of data reduction, data display, and continuous data verification. This technique could have been started when the research entered the data collection stage and finished when the researchers obtained an in-depth answer to the problem to draw the research conclusion. The data were validated through the data triangulation technique and verified by connecting the data obtained from observation, interviews, and documentation.

\section{FINDINGS AND DISCUSSION}

One of the objectives of the Visual Arts Education study program, Faculty of Language and Arts, Yogyakarta State University is to produce competent formal teachers. To achieve this objective, the study program has designed a curriculum in such a way. This department applies an aesthetic approach as a method to provide students with a concept of art appreciation and creation. Aesthetic sensitivity is taught in the theoretical subjects and applied to practical subjects, both implicitly and explicitly.

In DBAE, three basic approaches can be used to determine the aesthetic value of artworks, namely representation, expressionism, and formalism. These three approaches have their characteristics. The representation has a concept of the imitation and mimesis of an object; expressionism emphasizes feelings and emotions, whereas formalism illustrates the significance of the work structure. This aesthetic approach is applied to foster the aesthetic sensitivity of the students.

Based on the curriculum, Visual Arts Education applies an aesthetic approach to several visual art courses such as Fine arts, Applied arts, Sketching, Form drawing, Anatomical Drawing, Model Drawing, Nirmana, Illustrations, Ornaments, Photography, Aesthetics, Visual Arts Criticism, and so on. The aesthetic approach-based arts education applied to the Visual Arts Department curriculum is in line with the DBAE; aesthetic sensitivity is instilled far before the students produce artworks in both theoretical and practical subjects. At the beginning of the semester, students take practical courses that have more units of credit. The practical course is an overview and introduction to the principles of arts and art making before students get to know what aesthetics is. Each lecturer in this department has different teaching styles, but the essence of the aesthetic approach is the main focus.

One of the aesthetic approaches, formalism, is applied in subjects that focus on composing elements of visual arts, including Two-Dimensional Nirmana and Three-Dimensional Nirmana courses. These two courses encourage students to play the elements of art using the principles of visual arts. The aesthetic sensitivity of students appears when they select and arrange elements of art into an artwork. The key to the aesthetic approach through formalism is the organization of art elements such as lines, shapes, colors, and so on.

The second approach, imitation, is applied to the subjects of Form Drawing and Model Drawing. These two courses guide students to represent objects based on their characters. Students must try to capture visual objects including shape, proportion, and lightness and darkness. Students experience the character recognition of an object and illustrate it in artwork with various alternative creation choices. This course trains motor skills to get used to making strokes or shading and provides the students with practices that hone their abilities to select color tones.

The third aesthetic approach, expressionism is applied in several courses in visual arts and applied arts. These courses include painting, sculpture, printmaking, crafts, and so on. Before making an artwork, students must first determine the source of the idea for their creation through the exploration method. The object is not limited to living creatures or things, but it includes objects that have expressions of emotions and atmosphere. To help students read emotions, the lecturer first invites students to observe body movements, events, atmosphere, activities, or other things that can be used as objects of artworks. The lecturer invites students to explore human moods such as feelings of joy, sadness, and anger. In this case, various feelings can be visualized, but some cannot. What is unique about this expressionism approach is that cultural background affects the aesthetic sensitivity felt by each individual. The result shows everyone has a different way in conveying the emotional expression of a work.

In addition to the courses mentioned above, the aesthetic approach through representation and expressionism is applied by the Visual Arts Education department in the Sketching course. In this course, the lecturer leads students to find out the concept and function of a sketch. The lecturer does not immediately let the students start; he/she first invites students to capture the spirit of the object. The 
lecturer gives the example that only by using a broken egg, people can describe the atmosphere of a busy market. There is a story behind the egg breaking that makes us understand the bustling atmosphere of a market which can mess up things like an egg falling and breaking. Students understand that everyone has different thoughts and ways of expressing their emotions. This can educate students to be more sensitive to the emotions that exist in artworks, other people's emotions, and their own emotions.

Sketching course facilitates students to capture the character of an object and feel the emotions in it. For example, the lecturer asks the students to identify various places and atmosphere settings such as markets, lakes, sea, historical spots, or stations. Students can observe the object and atmosphere of the place, and then they explore the emotions they feel. Also, they select an object and need to think about the most appropriate composition and perspective for their artworks.

Representation, expressionism, and formalism are three aesthetic approaches that can make students change their views on art interpretation. Furthermore, aesthetic sensitivity and "what is art" are discussed in the aesthetic subject itself. The principle of the learning model used in this course is an inquiry, in which students ask questions of "what is art" and aesthetics. When students investigate and find various dynamic theories regarding the concept of aesthetics, they face a variety of experts' opinions that are similar, different, and even contradictory. This situation affects the student's appreciation pattern. They will realize that art is not a path with one goal but with a thousand directions that can lead them to the same or different goals. The aesthetic approach provides a great opportunity for students to actively participate in finding their own aesthetic experiences.

The aesthetic approach in the Visual Arts Department is not only used for the production or creation of arts. Through the Art Criticism course, students use their aesthetic sensitivity to appreciate arts and study works of art. The aesthetic approach can guide students to internalize the value and meaning of artwork from both subjective and objective perspectives. Formally, students can observe an artwork based on the organizational structure or arrangement of its visual arts elements. From that stage, students can judge works based on harmony, unity, balance, rhythm, composition, and so on. Furthermore, students can judge the representation by observing the imitation made by the artist of the work. In terms of expressionism, students can feel the emotions the artist wants to convey through the work. In representation and expressionism, students must exert themselves because not all forms and emotions are conveyed by the artist implicitly. This is the interesting part in analyzing an artwork; students have to explore more to obtain the appropriate analysis results. In examining artworks, the lecturer provides an alternative for students to use various analysis methods such as semiotics, hermeneutics, and the like.

The aesthetic approach applied by the Visual Arts Department is the initial foundation for the preparation of art teachers with character. The understanding of art and aesthetic experiences while studying at the Visual Arts Department determines how the prospective teachers introduce aesthetics to their students later. Three aesthetic approaches can be used by prospective teachers to learn how to view arts, including aesthetics, social, and innovation. Students and alumni of the Department of Visual Arts Education admit that aesthetic approach-based learning does not only change their view of art but also provides more significance. Aesthetic sensitivity in expressionism promotes their social skills, especially feeling emotions and atmosphere. This is because aesthetic experience builds emotional awareness in which they study the feelings of pleasure, happiness, love, sadness, fear, hatred, and the like.

Students explain that the formal aesthetic approach improves their accuracy, particularly, in terms of analysis and problem-solving. Representation triggers students' confidence to express ideas. Arts learning with an aesthetic approach can increase the ability to appreciate and create arts. The aesthetic approach offered by the Visual Arts Education Department in the courses allows the development of students' skills to create artworks and interpret aesthetics in a work. Therefore, aesthetic learning connects the three important dimensions, namely will, feel, and creation.

\section{CONCLUSIONS}

The availability of competent and characteroriented teachers is one of the requirements for the feasibility of arts learning. Department of Visual Arts Education, Yogyakarta State University is one of the higher education institutions that produce professional art teachers. This department applies various approaches in learning activities, one of which is aesthetic sensitivity learning. The aesthetic approach is applied to several courses through the methods of formalism, representation, and expressionism.

The formalism approach trains students' visual carefulness in developing elements of visual arts in a work. Representation improves the student's criticism on the form and character of an object. Expressionism 
teaches students to read emotions and explore ideas of pouring those feelings into a work. The three methods enrich students' perspectives on aesthetic values in an artwork. The result is that aesthetic sensitivity-based learning enhances appreciative attitude, critical attitude, self-confidence, creativity, and the like. These attitudes build the character and competence of prospective art teachers. Therefore, an aesthetic approach is significant for humanist education such as arts.

\section{REFERENCES}

[1] Loudermilk, Michelle Lynn. The Use of Aesthetics in a Comprehensive Art Curriculum. Theses, Dissertations, and Capstones. 2002. Unpublished.

[2] Malarsih, Malarsih, and Wadiyo Wadiyo. Pendidikan Estetika Melalui Seni Budaya Di Fakultas Bahasa Dan Seni Universitas Negeri Semarang [Aesthetic Education Through Cultural Arts at The Faculty of Language and Arts, Semarang State University]. Harmonia Journal of Arts Research and Education 9.1 (2009): 62238.

DOI:https://doi.org/10.15294/harmonia.v9i1.662

[3] Munteanu, Luminita Heliana dkk. Art and Moral Values - A Pedagogical Approach through the Hexadic Model. Procedia - Social and Behavioral Sciences, 83: 437- 442. 2013. DOI: 10.1016/j.sbspro.2013.06.086

[4] Upitis, Rena. Arts education for the development of the whole child. Elementary Teachers' Federation of Ontario, 2001.

[5] Wijayati, Hasna dan Indriyana R. Post Modernesime: Sebuah Pemikiran Filsuf Abad 20 [A 20 $0^{\text {th }}$ Century Philosopher's Thought]. Sociality: Yogyakarta. 2019.

[6] William, Jare. Art Education with Attitude. Journal of Social Science Education volume 15, Number, Winter 2016. DOI 10.2390/jsse-v15-i41491 